\title{
CAN HUMAN RIGHTS AND EQUALITY INSTITUTION OF TURKEY PLAY AN ACTIVE ROLE IN COMBATING DISCRIMINATION?
}

\author{
DOI: 10.17261/Pressacademia.2017.697
}

JEFA- V.4-ISS.3-2017(9)-p.296-303

\author{
Basak Gunes ${ }^{1}$ \\ ${ }^{1}$ Istanbul Techn,cal University, Istanbul, Turkey. basakgunes.bg@gmail.com
}

\section{To cite this document}

Gunes, B.,. (2017). Can human rights and equality institution of Turkey play an active role in combating discrimination?. Journal of Economics, Finance and Accounting (JEFA), V.4, Iss.3, p.296-303.

Permemant link to this document: http://doi.org/10.17261/Pressacademia.2017.697

Copyright: Published by PressAcademia and limited licenced re-use rights only.

\begin{abstract}
Purpose - This study investigates whether the Law No. 6701 on Human Rights and Equality Institution of Turkey (HREIT) will be effective in the struggle against discrimination in Turkey.

Methodology - This study critically evaluates the articles of the law from the perspective of human rights law.

Findings- This study determines that that the law considers only a limited number of issues as the basis for discrimination and in case of discrimination other than this limited number of underlying issues, one cannot apply to the Institution. Furthermore, the conditions to apply to the institution are challenging.

Conclusion- This study clarifies that when the current legal framework is taken into consideration, it unfortunately does not seem possible for HREIT to play an active role when combating discrimination.
\end{abstract}

Keywords: Human rights, discrimination, equality principle, prohibition of discrimination, the Law No. 6701 JEL Codes: K30, K31

\section{INTRODUCTION}

On 20 April 2016, the Law No. 6701 on Human Rights and Equality Institution of Turkey entered into force. The purpose of the law is gathering the (i) protection and development of human rights, (ii) combating discrimination and the right to receive equal treatment, and (iii) combating torture and maltreatment, which are all related to each other, under the same corporate body. (Odyakmaz, Keskin, Deniz: 2016, 733). The board members of Human Rights and Equality Institution of Turkey ("HREIT"; "the Institution") were selected on 16 March 2017 in line therewith. The chairman and the vice chairman of HIREIT were selected on 25 May 2017, when the Institution commenced its operations. Furnished with quasi-judicial authorities, the Institution is distinguished from other national mechanisms that lack the authority to take binding decisions. The Institution has quasi-judicial authorities such as (i) conducting ex-officio investigations regarding violation of human rights and prohibition of discrimination (Article 9-paragraphs $f$ and g), (ii) conducting reconciliation including termination of violation or making indemnity payment to the victim (Article-18-paragraph 3) and (iii) imposing administrative fines from TL 1,000 up to TL 15,000 based upon the procedures stipulated by the Law. (Bakirci: 2017,69.)

Although the Law no. 6701 appears like a law of association due to its name, the law essentially includes the fundamental principles regarding the prohibition of discrimination and definitions of various concepts along with the formation, duties and authorities of the HREIT. Therefore, the definitions under the scope of the Law no. 6701 attained positive foundations for the first time. When considering the authorities of the Institution along with the fact that the fundamental principles related to the prohibition of discrimination were covered by an extensive law for the first time, the question about whether we have entered a new era in combating discrimination might be raised. In this study the question pertaining to "whether HREIT can play an active role within this context or not" is assessed within the scope of the provisions (i) regarding the prohibition of discrimination and (ii) pertaining to HREIT under Law no. 6701. 


\section{PROVISIONS REGARDING THE PROHIBITION OF DISCRIMINATION STIPULATED UNDER LAW NO. 6701 ON HUMAN RIGHTS AND EQUALITY INSTITUTION OF TURKEY}

The two tendencies of (i) indicating the basis of discrimination and (ii) drafting open-ended regulations draw attention under international law and comparative law when the question regarding the prohibition of discrimination arises. The only sources of positive law other than Law no. 6701, in our country that relate to the prohibition of discrimination are the Article 10 of Constitution and Article 5 of Labor Law no. 4857. While the expression of "et cetera" is included within the scopes of both provisions, the points that constitute the foundation of prohibition of discrimination were indicated as numerus clausus within the Law no. 6701 (Bakirci: 2017, 74). Pursuant to the Article 3 of the Law no. 6701, all persons are equal with regards to the enjoyment of legally vested rights and freedoms (paragraph $\mathrm{f}$ ). It was indicated within the scope of the second paragraph of the article that discrimination based upon gender, race, color, language, religion, sect, philosophical and political opinion, ethnical origin, wealth, birth, marital status, health status, disability and age is prohibited.

Although the expressions "human rights" and "discrimination" were used within the scopes of the provisions pertaining to the duties and authorities of the Institution in general, as we have mentioned above, in the event of a discrimination based upon any foundation other than the foundations set out as numerus clausus, it shall not be possible to benefit from the protection granted by the Law no. 6701, because neither the letter of the third article, nor the statements within the scope of the article 2, which pertains to the definitions, allows so when comprising of direct discrimination, indirect discrimination, mobbing in the workplace, harassment, and discrimination based upon any assumed foundation. Indeed the preamble of the law is as follows: "While the subject of the discrimination is set out as "enjoyment of legally vested rights and freedoms", the foundations of discriminations are set out as "gender, race, color, language, religion, sect, philosophical and political opinion, ethnical origin, wealth, birth, marital status, health status, disability and age"; therefore, this deems the illegal prevention of enjoyment of rights and freedoms through any act and implementation based upon the abovementioned foundations as discrimination."

As it can be seen, discrimination based upon sexual orientation was not taken into the scope of the Law no. 6701 . Considering that the LGBTI persons are among the groups that are exposed to the highest level of discrimination as well as hate speech, there is no doubt that the lack of this point constitutes a huge deal of insufficiency. Indeed, the mentioned insufficiency was criticized within the scope of doctrine (Bakirci: 2017, p. 75) and European Union's Progress Report of Turkey for the year 2016. (EU Progress Report, p. 65).

When the exclusion of discrimination based upon sexual orientation is set aside, the scope of the prohibition of discrimination is designated as highly broad. Apart from the designated exclusions Law no. 6701 contains violations of prohibition of discrimination both within the public and private sectors. Thus, on one hand while prohibiting the discrimination committed by the natural persons and legal entities, the Law no. 6701 on the other hand provides protection for natural persons and legal entities that are exposed to discrimination. In terms of people, the Law no. comprises the persons who (i) wish to reach goods and services (Articles 5/1 and 3), (ii) wish to join various organizations and benefit from their facilities (Article 5/4) and (iii) are working as independent practitioners or employed workers (Article 6) (Bakirci: 2017, p. 72).

The Law no. 6701 designates a specific provision for work life. The Article 6 is as follows: "Employers or the persons that are authorized by the employers shall not commit discrimination to the detriment of any person that is present in a workplace or any person that applies for the mentioned purpose or any person that wishes to obtain information for the purpose of working under any capacity or for the purpose of gaining occupational experience or obtaining any information regarding the job during any processes in relation to the job including gaining information, application, criteria for selection, conditions of employment and the processes regarding the work and termination of working." Pursuant to the Article 6/II, the mentioned provision also applies to accessing all levels and types of job adverts, workplace, working conditions, occupational guidance, occupational training and occupational retraining; as well as progressing within one's career, and accessing all levels of occupational hierarchy, in-service training, social benefits, and such other elements. As it can be seen, the article, felicitously notwithstanding the law which it is related to, was designated in such way that it comprises all types of employment agreements, trainees and apprentices and written in a way that it applies to all work-related processes including job adverts. Comprising the expression "and such other elements", it was revealed that the elements that are mentioned within the scope of the provision serve as examples set for the situations.

One article of Law no. 6701 which, among others, is relatively more open to criticism is the Article 7 which sets out the cases where discrimination cannot be alleged. Accordingly, any allegation of discrimination as set out by Law no. 6701 cannot be made in the cases where; (i) in the event of requisite occupational requirements, different treatment that is proportional and fit for the purpose within employment and independent business areas; or (ii) cases that require the employment of a specific gender; or (iii) designation and implementation of age limits during admission and employment processes due to the requirements of the service; or (iv) special treatment based upon age -provided that it is necessary 
and proportional to the purpose-; or ( $v$ ) special measures and protection precautions for children or persons who should be kept in a special place; or (vi) employment of persons that have a specific religious belief by the institutions that belong to the mentioned specific religion for the purpose of offering religious services or providing; or (vii) the requirements set forth by the associations, charitable foundations, unions, political parties and professional organizations within their own relevant legislations or codes regarding specific conditions and eligibilities for the individuals who want to join them; or (viii) different treatment of non-citizens arising out of their legal statuses or conditions set out for their entrance to and residence within the country. Righteously indeed, it was stated by the doctrine that; (i) the expression "cases that require the employment of a specific gender" is much more extensive than the exclusions set out by the Labour Law no. 4857 to apply for female employees, (ii) it falls behind the Law no. 4857, and that (iii) it breaches the Discrimination Convention of International Labor Organization's (“ILO”) no. 111 (Odyakmaz, Keskin, Deniz: 2016, p.736). Indeed, since the Law no. 4857 has brought some prohibitions for female workers with respect to working in underground and submarine sites (Article 72) along with some other prohibitions with respect to maternity and nursing period, the broad interpretation of this provision might make it possible to legitimize certain acts of discrimination based upon gender.

\section{PROVISIONS OF LAW NO. 6701 PERTAINING TO THE HUMAN RIGHTS AND EQUALITY INSTITUTION OF TURKEY}

\subsection{Institutionalizing in the Field of Human Rights and Human Rights Commission in Turkey}

Ombudsperson institution being in the first place, various institutions stated cited as "national human rights institutions" have become widespread within the globe especially since 1970s. The mentioned institutions, which could generally be defined as permanent and independent institutions that were founded to serve the purpose of protecting and popularizing human rights, are usually founded under different names and forms in many states. While being organized individually based upon their fields of campaigning in some states, they are sometimes organized under a single body in the others. Thus, it is not possible to discuss a uniform structure when talking about human rights institutions. Having said that, "Principles Relating to the National Institutions", also known as "Paris Principles" were adopted for the purpose of designating standards to apply to the functions undertaken by these institutions by the United Nations ("UN") in 1993, as result of the studies that had been conducted since 1970s. Although the mentioned principles are of advisory nature and not binding, Paris Principles, which aim to clarify (i) the status of national human rights institutions; (ii) the standards they need to have and (iii) their definitions, bear political significance (Bakirci: 2017, p. 66-68, Ogusgil: 2015, p.177).

Initially the first step taken in Turkey about institutionalization within the field of human rights was taken through Law no. 3686 dated 05.12.1990, when Human Rights Investigation Commission was founded within the body of Grand National Assembly of Turkey ("GNAT") (Eren: 2016, p. 69). Along with the mentioned commission, there also is the Department of Human Rights, a unit that is currently a part of Prime Ministry Headquarters; and also Human Rights Councils of provinces and districts, High Council of Human Rights, which consists of undersecretaries of several ministries; Consultative Committee of Human Rights, which operates under Secretary of State; Human Rights Education Ten Year National Committee; Investigation Commissions of Alleged Violation of Human Rights, which are within the body of Prime Ministry; also GNAT Committee on Equality of Opportunity for Women and Men; and Prison Monitoring Boards. (For detailed information please see: Odyakmaz, Keskin, Deniz: 2016, 730 ff, Tezcan, Erdem, Sancakdar, Onok:2016,817 ff; Kilim, Sener, Demirbilek: 2014, $283 \mathrm{ff})$.

Apart from all the mentioned institutions, Human Rights Institution of Turkey, which was the pioneer of HREIT, was established by the Law no. 6332 dated 05.12.1990. Optional Protocol to the United Nations Convention against Torture and Other Cruel, Inhuman or Degrading Treatment or Punishment (“OPCAT"), to which Turkey is also a party, prescribed (i) establishing a national prevention mechanism which would function to prevent the cases of torture and maltreatment within jails, prisons, detention camps, and care centers by conducting surveillance, investigation, supervision, evaluation and reporting activities, or (ii) imposing the mentioned duty on the present human rights institutions. The mentioned duty of the aforesaid national mechanism was imposed on Human Rights Institution of Turkey by the Cabinet Decree no. 2013/5711 dated 09.12.2013. However, conveying such a responsibility to the mentioned institution came with the necessity of consolidating the capacity thereof. Thereupon, Law no. 6701, which has superseded Law no. 6332, was accepted and HREIT was established to substitute Human Rights Institution of Turkey.

\subsection{The Qualifications and Organizational Structure of HREIT}

Paris Principles primarily designate independence and assurance of authority for national institutions. In order to attain independence, it is vital that the institution (i) is established upon a legal basis, (ii) has a pluralist structure, (iii) has its own budget and staff, and (iv) designates its own working conditions; all the mentioned requirements being summed up as structural independence. Apart from these, it is important that the institution also has to have financial and functional autonomies. (Eren: 2016-79; Ogusgil: 2015, 179). Within the context of assurance of authority, national institutions should be furnished with a broad assurance of authority by the constitution or legislations in an implicit and detailed way in order 
to carry out their activities efficiently. Within this frame, the institutions must have the following authorities, which could be indicated as; (i) admitting and investigating the complaints and petitions delivered to itself; (ii) conducting visits to the places where human rights are being violated or is likely to be violated; (iii) obtaining any type of information and documents as well as hearing all the relevant persons whenever deemed necessary; (iv) preparing reports; and (v) submitting opinions and advises to the relevant institutions including the government and the parliament. (Ogusgil: 2015, p. 179.)

It was stated within the Article 8 of Law no. 6701 that HREIT is an institution which holds administrative and financial autonomies and a special budget with a public legal entity. Pursuant to the Article 10 of the Law no. 6701, the decision making body of the HREIT is Human Rights and Equality Commission.

Although, apart from the Article 8, Law no. 6701 comprises provisions to set out independency of HREIT such as; "The Commission carries out and uses its duties and authorities that are conveyed thereto by the Law and other legislations under its own responsibility. No other body, office, resort or person shall instruct, advise or inculcate the Commission regarding the issues that fall into its remit" (Article 10/I); and "The Commission shall assemble upon the summon of the Chairman... the agenda being set by the Chairman..." (Article 12/1 paragraph 1 and 2); "The Chairman... to assign the Institution staff" (Article 13/paragraph 2-ç); all the mentioned provisions lack importance unless the infrastructure and conditions of independence are in place (Eren: 2016, p. 80). Indeed, one of the most criticized provisions of the Law no. 6701 the provision that designates the composition of the Human Rights and Equality Commission. The Commission is comprised of 11 members, 8 of which are elected by the Cabinet while the other 3 shall be selected by the President of the Republic (Article 10/paragraph 2). It is set out by the provision that 1 member shall be elected from the 2 candidates that are recommended by the Council of Higher Education, among academicians who have conducted studies within the field of human rights; and other 7 members shall be elected from (i) the candidates named by non-governmental organizations, unions, social and occupational organizations, academicians, lawyers, press members of visual and written media and the field experts, and (ii) the individuals who have signed up for membership. There are not any provisions designated relating to the members to be selected by the President of the Republic. Even the essential points regarding the election system also was not included within the Law no. 6701. The statement of "having conducted studies within the field of human rights" is highly vague. For instance, will any non-governmental organization that has inscribed the protection of human rights as a cause within its code be eligible? Or, will an academician who has written a single article on human rights be eligible? Even more significant questions than all of the mentioned, will the Commission, whose entire members are elected by the executive power, be able to act independently of the executive power? Could the Commission be impartial with regards to the violation of human rights committed by the executive power itself?

Pursuant to one of the articles of the Paris Principles, titled as "Composition and Guarantees Of Independence and Pluralism"; he composition of the national institution and the appointment of its members, whether by means of an election or otherwise, shall be established in accordance with a procedure which affords all necessary guarantees to ensure the pluralist representation of the social forces (of civilian society) involved in the protection and promotion of human rights. It is very clear that the procedure set out by the Law no. 6701 does not qualify with the mentioned rules. It was stated within the scope of the Article that the mentioned aspect shall particularly be actualized by powers which will enable effective cooperation to be established with, or through the presence of, representatives of:

(a) Non-governmental organizations responsible for human rights and efforts to combat racial discrimination, trade unions, concerned social and professional organizations, for example, associations of lawyers, doctors, journalists and eminent scientists;

(b) Trends in philosophical or religious thought;

(c) Universities and qualified experts;

(d) Parliament;

(e) Government departments (if these are included, their representatives should participate in the deliberations only in an advisory capacity).

Without a doubt, in order to provide pluralism, a procedure that enables the election of some of the members of the Human Rights and Equality Commission by the legislative branch, bar associations, non-governmental organizations or dissident representatives ought to be designated (Eren: 2016, p. 80). Particularly LGBTI persons, or individuals from ethnical and religious minorities, or non-governmental organizations that operate within the field of women's rights, who face the most severe discrimination within the society, should be able to participate in the mentioned election. On the other hand, while the 2 members out of 11, who were the part of the decision making body of the Human Rights Institution of Turkey, used to be elected by the universities and bar associations; the mentioned point was entirely dismissed with respect to the composition of the decision making body of HREIT, which is the successor of the Human Rights Commission. 
Pursuant to the Paris Principles, the national organizations must have a convenient infrastructure, and especially sufficient financial resources, in order to carry out their works properly. There resources should enable the employment of their own staff and having their own venues. Therefore, the relevant organizations can be independent from the government and they will not be subject to any financial control which could challenge their independence.

The treasury contributions that are going to be conducted from the general budget, the revenues to be acquired through the movable and the immovable property that belong to the Institution; the income acquired from valorizing the revenues and other revenues are stated to be among the revenues of the Institution within the scope of the Article 23 of Law no. 6701. However, as it was also indicated within the scope of European Union's Progress Report of Turkey for the year 2016, not any functional, structural and/or financial independencies were granted to the Institution (EU Progress Report, p. 76). Pursuant to the Law of Budget of the year 2017, the total amount of budget allocated to the HREIT for the year 2017 is TL $6,844,000$. TL 2,082,000 of the total amount was spared for the staff costs (Central Administration Law of Budget for the year 2017, Table no. II, Official Gazette no. 29928 bis, dated 24.12.2016). To set an example; the total amount of budget allocated to the Supreme Board of Radio and Television is TL 181,000,000 for the year 2017. TL 125,668,000 of the total amount was spared for the staff thereof (Central Administration Law of Budget for the year 2017, Table no. III). The budget spared for the staff of HREIT, which was established in order to combat discrimination, torture and maltreatment throughout entire Turkey is as about much as one sixtieth of the budget allocated to the staff of the Supreme Board of Radio and Television. In this context, it is clear that the Institution will experience a serious lack of infrastructure and labor force. Indeed, a staff consisting of 150 persons was allocated to the Institution.

There are also some articles within the Law no. 6701 that overshadow the administrative autonomy of the Institution. Pursuant to the Article 14/paragraph 5 of the Law no. 6701, when deemed necessary, bureaus that are affiliated to the Institution may be founded upon the proposal of the Institution by a Cabinet Decree. As it can be seen, the Institution is not authorized to found bureaus directly. The Cabinet was given the mentioned power instead. In addition to this, pursuant to the Article 14/paragraph 6; "The working procedures and principles of service units and bureaus are set out by the regulation brought into force by the Cabinet Decree upon the proposal and in compliance with the activity fields, duties and authorities of the Institution." Therefore, the Institution is not even authorized to prepare the regulation regarding the units that are affiliated thereto. The mentioned provisions indicate administrative tutelage upon the Institution (Eren: 2016, p. 83).

Comparing HREIT to the "Rights Defender", which is the national human rights commission of France composed in light of the Paris Principles will give an idea about how functional HREIT could be. Rights Defender Institution (Le défenseur des droits) was composed of four different institutions, which initially used to function separately within the field of protection of rights and freedoms, by way of gathering all of them under a single body. The one institution among four that essentially used to combat discrimination was High Institution for Anti-Discrimination and Equality (Chevallier: 2011, p.434). The purpose of gathering all four institutions under the same body was constituting a more rational system for the protection of rights and synchronizing the applications being made to the institutions that share the mentioned purpose (CluzelMétayer:2011, p.448). The fundamental missions of the Institution are (i) protecting the rights via individual applications and (ii) promoting accessing the rights and equality (Leconte: 2016, p.61).

Rights Defender is an entirely autonomous institution. Over all, the mentioned autonomy includes financial autonomy in the first place. The expenditures of the institution is not subject to any type of approval mechanisms except for a subsequent audit performed by Court of Accounts. The budget of the institution is allocated by the budget law, but the institution holds autonomy over this budget. The internal operations and the distribution of work are regulated by the regulation that the institution issues. The staff of the institution is assigned by the institution itself (Chevallier: 2011, p.434). The institution holds a provincial organization and 450 deputies along with 230 public servants are in service throughout France (Leconte: 2016, p.61). The budget allocated to Rights Defender for the year 2015 was $€ 27,436,842$ (http://www.defenseurdesdroits.fr/fr/rapport-annuel-dactivite-2015/finances-et-ressources-humaines, 10.05.2017).

\subsection{The Duties and Authorities of Human Rights and Equality Institution}

As we have indicated above, pursuant to the Paris Principles, national human rights institutions should be furnished with a broad assurance of authority by the constitution or legislations in an implicit and detailed way in order to carry out their activities efficiently (Ogusgil: 2015, p. 179). The duties and authorities of HREIT were designated within the Article 9 of Law no. 6701. Pursuant to the relevant provision, the Institution has highly broad duties and authorities such as; (i) conducting studies with respect to the protection and development of human rights, prevention of discrimination and elimination of violations; (ii) enhancement of public sensibility towards this subject by furnishing information and giving education; (iii) contributing to the preparation of chapters dedicated to human rights and prohibition of discrimination within the curriculum; (iv) conducting joint activities with the universities; (v) ex-officio investigation, prospection, conclusion and follow-up the consequences of violation of human rights and prohibition of discrimination; (vi) providing guidance to the Institution applicants regarding the administrative and legal processes they can utilize in order to eliminate their suffering; 
(vii) taking on the task to act as a national prevention mechanism to combat torture and maltreatment as well as conducting studies within the mentioned fields; (viii) investigation, prospection, conclusion and follow-up the consequences of the applications of the individuals that are deprived of their liberties or put under protection; and (ix) making announced or unannounced visits to the places that the mentioned deprived are located in.

That being said, the most fundamental activity of HREIT that will enable HREIT to make a difference within the practice is the investigation of individual applications. It was initially possible to make individual applications to Human Rights Institution of Turkey; however, pursuant to the Article 4 of the Law no. 6332, the only authority of Human Rights Institution of Turkey in line with the mentioned applications was investigating them, following up the consequences thereof, and undertaking attempts to solve the problems thereof. In addition to the mentioned, pursuant to the Article 17 of The Regulation on the Procedures and Principles with Respect to the Investigation of Applications Relating to the Allegations of Violation of Human Rights, Human Rights Institution of Turkey was capable of proposing reconciliation. Pursuant to the Article $18 / 3$ of Law no. 6701, HREIT may also invite the parties to reconciliation either ex-officio or upon request. However, the reconciliation process conducted by HREIT may result in (i) putting an end to the practice which was alleged to be the violation of human rights or prohibition of discrimination; (ii) or solutions which could comprise the mentioned result from the victim's point of view; or (iii) payment of a certain amount of compensation to the victim. The sanction to be imposed by the Institution when it ascertains that an act of discrimination is conducted is imposing an administrative fine between TL 1.000 and TL 15.000 within the scope of Article 25 of Law no. 6701. On the other hand, the Institution may, for one time only, convert the administrative fine into reprimand sanction. If the act of the person or the institution who had been reprimanded repeats the act of discrimination, the penalty shall be increased with a rate of hundred and fifty percent. As it can be seen, unlike Human Rights Institution of Turkey, HREIT is authorized to make binding decisions due to being furnished with quasi-judicial authorities (Bakirci: 2017, p. 69).

Pursuant to the Article 17 of Law no. 6701, any natural person or legal entity, who claims that they have been discriminated, may apply to HREIT. The application may be submitted through governorates in provinces and vicegovernorates in the districts. The applications are made free of charge. Also, being a citizen is not a prerequisite of applying to HREIT. There is no doubt that the mentioned provisions are very appropriate.

On the other hand, it was designated within the scope of the Law no. 6701 that the applicants must first request from the relevant party the amendment of the practice that they claim is contrary to the Law no. 6701 before applying to HREIT. Designating such conditions with respect to the investigation of individual applications, which are the basic activities that are capable of deeming the Institution functional, will complicate the applications, especially the applications made by the persons who are in hierarchical relation with the perpetrator of the act of discrimination.

Moreover, the Article 17/5 of the Law no. 6701 sets out that "The applications relating to the allegations of discrimination within the scope of the Article 5 of the Law no. 4857 may be made in the cases where no decision regarding a sanction is made following the pursuance of complaint procedures designated within the scope of the Law no. 4857 and the relevant legislation." Being among the individual labor codes, Labor Law no. 4857 comprises regulations that apply to a great amount of workers. As we mentioned earlier, the Article 5 is also relevant to the prohibition of acts of discrimination committed by the employer. However, no complaint procedure was set out within the scope of the mentioned article. Article 5 conveys the opportunities to the workers to claim compensation and the rights that they had been deprived of. Therefore, the implementation of this article is uncertain.

It was stated within the scope of the Law no. 6701 that "the persons that claim to suffer from the violation of prohibition of discrimination" may apply to the Institution. It was designated within the scope of the Provisional Article 1 that regulations regarding the implementation of the Law shall be put into effect within six months as of the date of the Commission's first assembly and that the applications regarding the prohibition of discrimination shall be admitted as of the date when the mentioned regulation enters into force. However, although it has nearly been a year since the entrance to the effect of the Law no. 6701, there has yet not been any regulations prepared as of June 2017. The same expressions were also used within the scope of Law no. 6332 concerning the individual applications; however, it was indicated within the scope of the Article 4 of Regulation on the Procedures and Principles with Respect to the Investigation of Applications Relating to the Allegations of Violation of Human Rights that the application may be made by the persons whose current and personal rights are affected directly from the operation, act or omission that is alleged to cause the violation. However, as indicated by the article, the possible victims shall also be able to benefit from this right. Pursuant to the Article, "Legal entities may make applications regarding the subjects that concern them or their members. The victim or a relative of the victim shall be contacted to provide consent within the scope of the applications made for the benefit of the victim by natural persons or legal entities. If the consent is not reported, the decision regarding not making any decision is taken. However, in the cases where the subject thereof constitutes a crime, the condition to obtain the consent may not apply." Considering the provision within the scope of the Law no. 6701 regarding the requirement pertaining to the claim of the persons about the amendment of the practice which they claim to be contrary to the Law before applying to HREIT, it is possible to say that 
the right to individual application shall only be enjoyed by the persons who claim to suffer from absolute violation of prohibition of discrimination. There is not any doubt that the mentioned limitation is not a fair option.

Should the need arise to come back to the case of France, it is also free of charge to apply to Rights Defender and just as it is with the HREIT, no condition regarding citizenship is required when applying to Rights Defender. However, unlike HREIT, associations which have been active for more than five years and which have causes inscribed within the scope of their codes that are relevant to the subject of their application may also make application. Likewise, the right to make an application is also granted to some public authorities concerning certain aspects (Cluzel-Métayer: 2011, p.449). Rights Defender may (i) conduct reconciliation procedure within the frame of the applications made to itself; (ii) issue individual or general advisory decisions; (iii) bring reform proposals and (iv) declare its opinion within the scope of lawsuits. As of the year 2016, more than $60 \%$ of these opinions were taken into consideration by the judges and also more than $80 \%$ of the activities within the scope of reconciliation was successful (Leconte:2016, p.61). 138,596 applications were made to the Rights Defender in the year 2015 (http://www.vie-publique.fr/actualite/alaune/rapport-2016-du-defenseur-droits-activitehausse-8-8.html, 10.05.2017). There has not any official publications or announcements made regarding the applications made to HREIT; however, Human Rights Institution of Turkey, which is the predecessor of HREIT, had received 815 applications during the year 2015 (http://www.tihek.gov.tr/tr/raporlar-ve-kararlar/istatistikler, 20.05.2017). The data herein stated is only about the number of applications. Other than the mentioned, the Institution has issued 10 investigation reports and 1 decision between the years 2014-2016. There is not any other solid data regarding the activities of the institution.

\section{CONCLUSION}

The most fundamental innovation brought by the Law no. 6701 is the definitions regarding the concepts pertaining to the discrimination. The mentioned concepts under the scope of the Law no. 6701 attained positive foundations for the first time. Apart from the Article 10 of the Constitution, this is the first time of designating a general provision pertaining to the prohibition of discrimination. On the other hand, the limitation of foundations of discrimination within the scope of the Law no. 6701 and the exclusion of discrimination based upon sexual orientation cause a significant segment of society to be excluded from the scope of the Law no. 6701.

Although it was indicated within the scope of the preamble of the Law that it was aimed through the Law no. 6701 that (i) strengthening the institutional capacity of the current Human Rights Institution of Turkey and increasing the efficiency thereof; and (ii) regulating the fundamental legal framework and institutional structure concerning the prohibition of discrimination and equal treatment, and (iii) increasing the efficiency and functionality of the national prevention mechanism against the torture and maltreatment; the Institution lacks the organizational structure and financial autonomy sufficient to achieve the mentioned purposes. Likewise, the election of the decision making body of the Institution entirely by the executive power overshadows the independency of the Institution that is vital for the implementation of the mentioned objective. Apart from all, the requirement pertaining to the claim of the persons about the amendment of the practice which they claim to be contrary to the Law before applying to HREIT is a serious obstacle before the individual applications, which are basic activities that are capable of deeming the Institution functional.

To conclude, when the current legal framework is taken into consideration, it unfortunately does not seem possible for HREIT to play an active role when combating discrimination. 


\section{REFERENCES}

Bakirci, K. (2017). An Assessment on the Relevant Provisions of Equality Institution Law, the Constitution, and Labor Law, The Congress of Labor 2, Istanbul, p. 65-75.

Chevallier, J. (2011), “Le Défenseur des droits: unité ou diversité?”, Revue française d’administration publique, 2011/3 (no. 139), p.433-445. Cluzel-Métayer, L. (2011), "Réflexion a propos de la saisine du Défenseur des droits", ?", Revue française d'administration publique, 2011/3 (no. 139), p.447-460.

Eren, H. (2016). Human Rights and Equality Institution of Turkey, 2016.

Leconte, V. (2016), "L'intervention du Défenseur des droits en matiere de protection sociale des femmes", Regards, 2016/2(No.50), p.61-74.

Odyakmaz, Z., Keskin, B., Deniz, Y. (2016). "An Assessment on Law No. 6701 on Human Rights and Equality Institution of Turkey-1”, Journal of Court of Jurisdictional Disputes, No. 7, p. 721-761.

Ogusgil, V. A. (2015), "An Assessment of Human Rights Institution of Turkey In Light of United Nations Paris Principles on the Way to the European Union", Turkish World Journal of Social Sciences, No 74, p. 175-198.

Tezcan, D., Erdem M., R., Sancakdar, O., Onok, R., M. (2016), Manual of Human Rights, $6^{\text {th }}$ Edition

European Commission, Turkey 2016 Report,

http://www.ab.gov.tr/files/5\%20Ekim/son 2016 ilerleme raporu tr.pdf 